\title{
Using of red palm oil as milk fat healthy replacer in ice milk
}

\author{
M. E. Abd- ElGhany ${ }^{1,}{ }^{*}$, A. M. Hegazy ${ }^{1}$, A. M. Basuny ${ }^{2}$ and A. N. Zaghlool ${ }^{1}$ \\ ${ }^{1}$ Department of Food Science and Technology, Faculty of Agriculture, Al-Azhar University, Cairo, Egypt \\ ${ }^{2}$ Biochemistry Department, Faculty of Agriculture, Beni-Suef University, Beni-Suef, Egypt \\ * Corresponding author email: MaherAbdelghany2465.el@azhar.edu.eg (M. El-Ghany)
}

\begin{abstract}
This research was performed to throw the light on the use of fresh red palm oil as milk fat substitute in formula of ice milk, and to investigate the effect of this replacement on the quality characteristics at different concentrations. Ice milk samples were prepared by substituting $25,50,75$ and $100 \%$ of milk fat in control mix (5\%) with red palm oil. We investigated physico-chemical properties of red palm oil (refractive index, color, acid value, peroxide value, iodine number, saponification number and unsaponifiable matter), total phenols, tocopherol content, fatty acid composition and oxidative stability. Using of red palm oil at different concentrations led to increase the content of carotenoid and vitamin $\mathrm{E}$ and caused either improvement or retention of physiochemical quality criteria ( $\mathrm{pH}$ value, acidity, overrun, melting rate, fatty acids, color values, sensory, carotenoid and vitamin E). The appearance of ice milk was affected by the amount of red palm oil. Incorporation was positively correlated to yellowness intensity, when the ratio of red palm oil to whipping cream increased from $25 \%$ to $100 \%$ treatments. Also, ice milk produced with red palm oil containing 25 and $50 \%$ showed similar or even better-quality characteristics with respect to samples made with milk fat. In conclusion, the combination of red palm oil contributes to more intensity in yellowness as beta carotene, vitamin E, viscosity and percentage of overrun of formulation.
\end{abstract}

Keywords: Red palm oil, ice milk, physico-chemical properties, fatty acid, phytonutrients.

\section{INTRODUCTION}

Palm oil is becoming increasingly important worldwide. Palm oil and its fractions (olein and stearin) are used in different food applications, such as cooking oil for various type of dishes, frying oil and manufacturing shortening and margarine (Siew, 2005 and Nor Aini and Miskandar 2007).

The characteristic red color of red palm oil is due to the multi-carotenoids present in the oil, totaling about $575 \mathrm{ppm}$ with $90 \%$ as the provitamin A carotenoid, especially b-carotene and a-carotene. Meanwhile, tocopherols (vitamin E) and tocotrienols (provitamin E) are powerful antioxidants that confer oxidative stability to RPO as well as help to keep the carotenoids and other quality parametersn of the oil stable (El-Hadad et al., 2010).

Red palm oil (RPO) is an antioxidant rich oil which contains approximately $50 \%$ saturated and $50 \%$ unsaturated fatty acids. Carotenoids and vitamin $\mathrm{E}$ ( $75 \%$ of which is tocotrienol) are the most abundant antioxidants in this oil. Both of these antioxidants are contained at a level of at least $500 \mathrm{ppm}$ in RPO .The cocktail of antioxidants within RPO is believed to have synergistic effects (Szucs et al., 2011).Red palm oil supplementation has been used successfully to elevate vitamin A content in human diet, such as utilizing RPO in cakes, biscuits, bread, cookies, rusks and red shortening (Butt et al., 2006).
In today's world, consumers are more and more conscious about the very strong relationships between health and nutrition. That has fueled the interest on the development and commercialization of healthier and improved foods with better nutritional value; in order to not only offer a benefit to the healthconscious consumer but also to fight against potentially damaging nutritional deficiencies. Functional foods are those containing biologically active components, offering health benefits, and reducing the risk to suffer several common diseases (Santillan-Urquiza et al., 2017).

Ice cream is a frozen product consumed all over the world in dairy products. After the first and general definition, ice creams have been defined as food systems called polyphasic. These daily products include ice crystals, air bubbles, protein-hydrocolloid structures, a cry concentrated aqueous phase, emulsified fat, proteins and salts. In this regard, ice creams may be evaluated as oil-in-water emulsions (Cruz et al., 2009).

In ice cream, fat and fat structure development tissue has a critical prescription for many features. These properties include stability, optimal structure and physical properties as an example. Also, fat network governs many desirable quality properties. It produces a smooth characteristic, increases the richness of flavor in ice cream, a good carrier 
and synergist for added flavor compounds, helps to stabilize the foam, largely responsible for the creamy texture, contributes good melting properties, helps to provide ice cream structure, aids in lubricating the freezer barrel while the ice cream is being frozen (Fox, 2013).

In Egypt and according to Egyptian standards (2005) the fat content of ice milk must not less than 3\%. Australia and New Zealand require not more than $3 \mathrm{~g}$ fat per $100 \mathrm{~g}$ of ice cream. In Canada, this product with $3-5 \%$ fat by weight is labeled ice milk (Goff and Hartel 2013).

In Malaysia and other countries, palm oils are often used in ice cream manufacturing, selected to take into account physical characteristics, flavour, availability, stability during storage and cost. Palm mid-fraction, palm olein, palm kernel oil, red palm olein and blends of this oil in appropriate proportions can be used. Palm oils as a fat source in ice cream have the advantage that they can be used without modifying processes such as esterification and hydrogenation, which can produce trans- acids, which are not good for health. Furthermore, the cholesterol content of palm oil is lower than that of milk fat, and it can be consumed by those who are lactose intolerant (Nazaruddin et al., 2008).

This paper aims to use red palm oil as fat substitute in formula of ice milk, and investigate the effect of this replacement on the quality characteristics at different concentrations. Ice milk was prepared by substituting 25, 50, 75 and $100 \%$ of milk fat in control mix (5\%) with red palm oil.

\section{MATERIALS AND METHOD}

\section{Materials}

\section{Red palm oil}

Elais guineensis was obtained from processing units at ogbomoso in the western region of Nigeria.

Fresh buffalo's milk ( $6 \%$ fat) supplied by the farm of Faculty of Agriculture, Al-Azhar University, Cairo, Egypt. The Fresh buffalo's milk was separated to obtained fresh skim milk and fresh cream (50\% fat), cremodan obtained from Danisco, Cairo, Egypt.

Skim milk powder (S.M.P) (34\% protein, and $4 \%$ moisture) was obtained from (The Nile Commercial CO.), Cairo, Egypt.

Mango (Mangifera indica) was obtained from local market at Giza, Egypt.

\section{Reagents:}

All chemical and reagents of the analytical methods used in present study was at analytical grade. All chemical (chloroform, petroleum ether and ethyl alcohol) were purchased from El- Gamhouria Trading Chemicals and Drugs Company, Egypt. Pure standards of fatty acids methyl esters were produced by Koch light Laboratories, Ltd, England. All solvents ware distilled.

\section{Methods:}

\section{Separation of fresh buffalo's milk:}

The Fresh buffalo's milk was separated to obtained fresh skim milk and fresh cream (50\% fat), this method according to Li et al., (2016).

\section{Preparation of mango pulp:}

Mango were sorted, cleaned, washed, processed and homogenized by ultra truxx for 5 min until obtaining a homogenous mass, then treated in steam jacketed vessel at $80^{\circ} \mathrm{C}$ for 1 minute, pulp was extracted by means of a fine pulper in order to get homogenous textured pulp and then cooled at room temperature. The citric acid $0.08 \%$ was added to the pulp. The resultant pulp were filled and placed into 200 $\mathrm{mL}$ sterilized vessels glass can, which was then stored in a frozen condition at $-18 \pm 2{ }^{\circ} \mathrm{C}$ for later use according to Kumar and Mishra (2003).

\section{Technological methods:}

Ice milk production:

The different formulations of ice milk prepared as shown in Table (1). The control ice milk formula consisted of $49.86 \%$ fresh skim milk, 5\% fat, 9.44\% skim milk powder, 15\% sugars, $0.7 \%$ Cremodan Se 734 Veg and 15\% mango pulp. This formulation was estimated according to Goof and Hartel (2013). The other treatments of ice milk formulation were prepared by partial replacement of milk fat with ascending levels of RPO $(25,50,75$ and $100 \%$ ) as shown in Table (1).

Ingredients were mixed together, mixes preheated up to $70 \mathrm{C}^{0}$ and homogenized by ultra truxx for $5 \mathrm{~min}$, pasteurization at $83^{\circ} \mathrm{C}$ for $15 \mathrm{~s}$, cooled to $5^{\circ} \mathrm{C}$ and aged at $5^{\circ} \mathrm{C}$ overnight, fruit's pulp $15 \%$ were added into the chilled mixes. The mixes were frozen in an ice cream machine then filled into plastic cups $80 \mathrm{~cm}^{3}$, covered and hardened in a deep freezer at $-30^{\circ} \mathrm{C}$ for $24 \mathrm{~h}$ before analysis. Three replicates were made from each treatment. 


\section{Physico-chemical properties:}

Refractive Index (RI), specific gravity, melting point, relative viscosity value, smoke point, acidity \%, peroxide value, iodine number, saponification number and Unsaponifiable matter for RPO and ice milk were determined according to the methods of A.O.A.C. (2016). The color of RPO and ice milk was measured with a Minolta CR-400 colorimeter (Minolta Model CR-400, Camera Company, Osaka /JAPAN). As described by Balthazar et al.,(2015).The pH values were measured using a digital $\mathrm{pH}$ meter according to the method described in A.O.A.C (2016).Overrun of ice milk was calculated using a standard $100 \mathrm{ml}$ cup according to Marshall et al., (2003).Melting rate of ice milk was determined according to (Kumar, 2013).The malonaldehyde compound content ( $\mathrm{mg} / \mathrm{kg}$ oil) was determined by using the procedure of Hoyland and Taylor (1991).

\section{Oxidative stability by Rancimat method:}

The oxidative stability of red palm oil was determined using an automated Rancimat device (Metrohm Ud.CH-9100 Herisau, Switzeland, model 679) according to Farhoosh and Moosavi (2007).

\section{Determination of fatty acid profile:}

The fatty acid profile for RPO and ice milk were determined as methyl ester by gas liquid chromatography. Methyl ester was prepared using $\mathrm{BF}_{3}$ in methanol as methylating agent according to the A.O.A.C. (2016).

\section{Determination of phytonutrients:}

Total phenolics content in RPO was determined by the Folin- Ciocalteu method as modified by Neo et al., (2008). Total carotenes and vitamin E, A and lycopene were determined in sample according to Dauqan et al., (2011).

\section{Sensory evaluation:}

Ice milk was sensory to evaluate flavor, body and texture, melting quality, appearance and overall acceptability of the resultant panelists; members of Dairy and Food science Departments, faculty of Agric., Al-Azhar Univ., Cairo, Egypt, by twenty panelists according to Lebesi and Tzia (2011).

\section{Statistical Analysis:}

Results other sensory evaluation was analyzed using one way analyze the Variance (ANOVA) using (SPSS 20.0 for Windows, SPSS Inc., Chicago, IL, USA). Duncan's Multiple
Range Test $(\mathrm{P} \leq 0.05)$ was to compare ice milk means.

\section{RESULTS AND DISCUSSION}

\section{Physico-chemical characteristics of fresh red palm oil:}

The physico-chemical properties of edible oils play an important role in assessing their quality, palatability and consumer acceptability, as well as they are related with the healthy safe quality criteria of these lipids and foodstuffs cooked or processed by using them (Coultate,2009). The physico-chemical properties of tested red palm oil are presented in Table (2).

The physical properties of tested red palm oil included that color (lightness, redness and yellowness color), Density, refractive index, smoke point, viscosity, and slip melting point were illustrated in Table (2). The color in red palm oil is light yellow to orange-red, depending on its carotenoid content according to Rossi et al., (2007) who reported that the $\mathrm{L}^{*} \mathrm{a}^{*} \mathrm{~b}^{*}$ value of Indonesian palm oil as 39.03, 47.35 and 67.26 , respectively. The red palm oil showed a higher $a^{*}$ value $(57.12), b^{*}$ value (63.26) and lower $L^{*}$ value (44.34). The chromatic color compound $\mathrm{a}^{*}$ indicates +red to -green. The increased positive value of $a^{*}$ indicates an increased value of red. The redness of samples correlated well with the carotenoid content. The color component $b^{*}$ indicates yellow to blue. These observations are in agreement with the results reported by Mba et al., (2015) who reported that the red palm oil is rich in minor components which include carotenoids (500-700 ppm). The density is an important parameter from the commercial point of view, since it is used for volume to weight conversions. The density of most edible oils is less than that of water. In general, the density of an oil decreases with molecular weight and increases with unsaturation. Also, it can be used as a purity indicator as shown in Table (2). It was found that the density of red palm oil was 0.9062 . These results are in agreement with those found by Gibon et al., (2007). The refractive index is related to the degree of saturation and to the ratio of cis and Trans double bonds as well as influenced by oxidation damage to the oil. Refractive index at $25{ }^{\circ} \mathrm{C}$ of red palm oil was 1.4552 . These may be due to the presence of high levels of saturated fatty acids in red palm oil as reported by Ebong and Isong (1999).

Pure substances have sharp melting points but oils and fats are complex mixtures of 
triglycerides and possess a melting range. From Table (2), it was observed that the melting point of red palm oil $38^{\circ} \mathrm{C}$. Red palm oil was semisolid texture at room temperature. It was relatively slow melting properties. These results are agreement with those obtained by Edem, (2002) and Nor-Aini and Miskandar (2007). The smoke point of red palm oil as indicated in Table (2) ware $\left(235^{\circ} \mathrm{C}\right)$. According to Berger, (2007), the recommended smoke point for palm oil must be above $215^{\circ} \mathrm{C}$ (preferably above $220^{\circ} \mathrm{C}$ ) and smoke point of oil is dependent on the content of some minor component especially the free fatty acids. The slip melting point of red palm oil $\left(37.00^{\circ} \mathrm{C}\right)$. The highest temperature indicating it is more saturated. The increase in slip melting characteristics of palm oil are generally due to redistribution of the fatty acid chains within the triacylglycerol molecules (Sellami et al., 2012). The viscosity of oils is positively related to its melting point, thus it increases with high saturation and decrease with unsaturation as well as chain length. Consequence of that, the highest viscosity value (400 centipois) was detected in RPO. This value was due to the arrangement of acyl chains of fatty acids on the glycerol backbone of the triglyceride molecule, also the chemical properties of the oils such as chain length and saturation/unsaturation. These observations are nearly agreed with Naghshineh et al., (2010).

The chemical properties of tested red palm oil included that acidity, iodine value and saponification value were recorded in Table (2). Acidity is present in oils as a minor component and as a product of hydrolysis by lipase enzymes or by water reacting with tri acyl glycerols. Acidity is the most used criterion for determining the quality of oil. Red palm oil contains lowest amount of acidity $(0.19 \%)$ These results are agreement with those obtained by Gee, (2007). The iodine value is a measure of the unsaturated of oil. It is one of the parameters used to measure the quality of the oil (Mamat et al., 2005). Data showed that iodine value of red palm oil was 59.10. These obtained results indicated that the tested oil had reasonable amounts of saturated fatty acids owing to their relatively low iodine value, indicating a high resistant to oxidation which was associated with good quality and long shelf life. The values of the obtained results are in accordance to those obtained by Gee, (2007). The excellent resistance of red palm oil was an account of their lower iodine values, infrequently linoleic acid contents and the relatively higher percentages of unsaponifiable matter. The obtained results are in agreement with those of Alina et al., (2012) and Beku, (2015).

As presented in the same Table (2), the highest saponification value of red palm oil (193.42) $\mathrm{mg} \mathrm{KOH} / \mathrm{g}$ oil, this observation is based on the fact that long chain fatty acids or their acyl chains have low saponification values. This result was relatively with those found by Gupta, (2017).

Concerning the unsaponifiable matter, the values of red palm oil (1.33\%). These high values were due to their high concentration of vitamin E and carotenoids; this observation is closed to that of Kumar et al., (2016).

\section{Oxidative stability (Rancimat induction period) of red palm oil:}

Oxidative stability is a measure of oil and fat resistance to oxidation, because the process takes place through a chain reaction, the oxidation reaction has a period when it is relatively slow, before it suddenly speeds up. The time for this to happen is called the "induction time "and it is repeatable under identical condition (temperature, air flow, etc.). There are a number of ways to measure the progress of the oxidation reaction. Oxidative stability involved that peroxide value, thiobarabituric acid and induction period (hrs) was tabulated in Table (2). The peroxide value is defined as the amount of peroxide oxygen per kilogram of oil; traditionally this was expressed in units of millieqviualnts. The peroxide value (PV) is an indicator of the primary level of oxidation. The results cited in Table (2) showed that PV of red palm oil was 0.82 . These results are approximately agreement with Alina et al., (2012). Thiobarbituric acid (TBA) value measures secondary lipid oxidation products, which responsible for the rancid taste developed during storage. The results in same Table showed that TBA of red palm oil was 0.08 the obtained results are in agreement with those of Kirk and Sawyer (1991) and Riuz et al., (2001).

As regards the induction period (hrs) is one of the most popular methods currently in use is the rancimat method (Mariod et al., 2014).The data indicated that, red palm oil had the superior induction period being $71.00 \mathrm{hr}$. consequence of that, red palm oil is a potent anti-oxidant rich oil which consists of carotenoids, tocopherols, tocotrienols and lycopenes, as well as lipid fractions such as squalene, saturated and unsaturated fatty acids (which maximize absorption of these antioxidants).Alpha and beta-carotene account for $>90 \%$ of the total carotene in red palm oil. The 
obtained results are nearly in agreement with Rooyen et al. (2008) and Leonardis et al., (2016).

\section{Fatty acid composition of tested fresh red palm oil:}

Results in Table (3) showed that the percentage of total saturated fatty acids, total unsaturated fatty acids and total polyunsaturated fatty acid of red palm oil were (44.75, 43.16 and $12.10 \%)$ respectively. The fatty acid composition of red palm oil which has been identified by GLC contains (37.79\%) palmitic acid $\left(\mathrm{C}_{16: 0}\right)$ and $(42.60 \%)$ oleic acid ( $\mathrm{C}_{18: 1)}$.It was clearly noticed that palmitic was the most prevalent saturated fatty acid in this oil, However, low percentages of stearic acid $(4.83 \%)$ were found in this oil besides inconsiderable quantities of the other saturated acids which their percentage accounted $1.78 \%$.

As for the unsaturated fatty acids, it is seen that oleic acid was the most prevalent acid in red palm oil; it contained (42.0\%). Linoleic acid; it amounted $11.65 \%$, however linolenic acid and other unsaturated fatty acids were found in negligible amounts. It could be noticed that each one at the USFA was presented in RPO in its highest percentage, these results are nearly in agreement with Naghshineh et al., (2010) and Kumar and Krishna (2014). Also Ong and Goh (2002) studied the fatty acid composition of palm oil, and they reported that fatty acid composition of palm oil was as follows: 0.2, 1.1, $44.3,4.6,39.0,10.5$, and $0.3 \%$ of $\mathrm{C} 12, \mathrm{C} 14, \mathrm{C} 16$, C18, C18:1, C18:2, and (C16:1, C18:3).

\section{Phytonutrients of red palm oil:}

Results in Table (4) showed that $\mathrm{B}$-carotene, vitamins E, A, Lycopene and phenolic compounds in red palm oil. It also shows their Recommended Dietary Allowance (RDA) as established by the Institute of Medicine for different population besides, the amounts in grams of red palm oil that supplies the RDA. The data indicated that red palm oil is rich sources of micro components that serve therapeutic and antioxidants roles especially $\beta$ carotene and vitamin $\mathrm{E}$, besides their contents of vitamins A, Lycopene and Phenolic Compounds.

Red palm oil is the highest content of minor components it contained considerable amount of $\beta$-Carotenes 650.33ppm, vitamin E $710 \mathrm{ppm}$, vitamin $\mathrm{E}$ isomers consist of saturated tocopherols and unsaturated tocotrienols. There are five vitamin $\mathrm{E}$ isomers in red palm oil; $\alpha$-and $\gamma$-tocopherol; and $\alpha-\gamma-$ and $\delta$ tocotrienols. Approximately $70 \%$ of vitamin $\mathrm{E}$ in red palm oil is in the form of tocotrienols which are more potent antioxidants (Cassiday, 2017).Red palm oil contained infrequent amounts of vitamin A (1.72 ppm).These amounts are not sufficient to supply the RDA, on the authority of this, it need taking up a great amount of red palm oil being approximately 348.83 grams, in spite of this; the super abundance content of $\beta$ - carotene in this oil which accounted $650.33 \mathrm{ppm}$ in red palm oil is supported to meet the requirement of vitamin.

It was reported by Van Jaarsveld et al., (2006) that $12 \mu \mathrm{g} \beta$-carotene can provide $1 \mu \mathrm{g}$ retinol equivalent (RE), dependence of this, $650.33 \mu \mathrm{g}$ $\beta$-carotene in red palm oil can provide $54.20 \mathrm{ug}$ retinol, thereby the calculated amounts of red palm oil to supply the RDA of retinol (vitamin A) were 11.07 grams. By that means, 2 teaspoon (11g) of red palm oil will supply the RDA of vitamin $\mathrm{A}$ for adults. Consequence of that, supplementation of 1 teaspoon (5.5) of these oils will recommend to maintain sufficient vitamin A for infants and children. As shown in Table 4, red palm oil is rich in phenolic acid compounds. It was noticed that red palm oil had highest content of phenolics which were 220.34ppm. The phenolic acids are potent antioxidants and serve therapeutic role and nutritional benefits.

\section{Physiochemical properties of ice milk and} their different treatments:

As shown in Table (5) the statistical analysis of data shows that the fresh cream substitution of RPO has no significant effect $(\mathrm{P} \leq 0.05)$ on ice milk $\mathrm{pH}$ value and acidity. However, the $\mathrm{pH}$ values ranged from 6.14 to 6.20 in terms of $\mathrm{pH}$ values. This decrease in $\mathrm{pH}$ in all mixes may be due to the lower $\mathrm{pH}$ of fruits pulp, actually 4.9 for mango. These results are nearly in agreement with Galoburda et al., (2014) and ElSheshetawy et al., (2016).

The titratable acidity for formulated ice milk ranged from 0.29 to $0.33 \%$, the apparent acidity of ice milk mixes was due to the milk proteins, mineral salts and dissolved carbon dioxide, and our results are in agreement with those reported by Marshall et al., (2003) and Lim et al., (2010).

The obtained data from the same Table (5) showed that, the viscosity of ice milk mixes decreased as the proportion of RPO was increased, the viscosity values ranged from 22 to 27 centipois. This may be explained by the different degree of fat crystallization occurring in the milk fat and the RPO of globules at the refrigeration temperature $\left(5^{\circ} \mathrm{C}\right)$. It can be expected that an ice milk mix which had a higher amount of milk fat would have more fat crystals formed during aging process when 
compared with an ice milk. The decrease in viscosity of RPO mixes may be attributed to the higher content of total mono unsaturated fatty acids (MUFAs) and total poly unsaturated fatty acids of RPO compared to the fresh cream and the differences in melting point and fatty acid composition of the RPO used. A similar trend of result was previously found by Rosnani et al., (2007).

Finally, incorporation of RPO in all treatments had significant effect on the viscosity as compared to control, whereas $75 \%$ and $100 \%$ RPO substitution treatments lowered the viscosity of the mixes significantly as compared to control. These results are nearly agreement with Nazaruddin et al., (2008) and Al-Assar, (2009).

\section{Overrun and melting rate of ice milk and their different treatments:}

Overrun is the terms used to indicate the volume of air incorporated during the freezing operation. The more air added, the greater is the volume of ice milk produced and the higher is the overrun. From Table (6) it could be noticed that the highest overrun was for the $25 \% \mathrm{RPO}$ ice milk then $50 \%$ RPO substitute ice milk. Also, it could be observed that the lowest overrun was for $75 \%$ and fresh cream substitution $100 \%$ with RPO. Generally, overrun decreased slightly significantly $(p \leq 0.05)$ when RPO used especially at high concentrations. This result was nearly in agreement with Nazaruddin et al., (2008) and Corradini et al., (2014).

The decrease of overrun may be attributed the higher content of total mono unsaturated fatty acids (MUFAs) and total poly unsaturated fatty acids PUFAs of RPO compared to the fresh cream. The reduced aeration is reasonable for this decrease in overrun, as the oilier nature of RPO may not be enough to withstand the physical structure that support the air cells introduced during whipping. Moreover, the nature of high viscosity for fruits pulp, which had a negative effect on the overrun values, these results are nearly in agreement with those reported by Bajwa et al., (2003) and Guven et al., (2018).

The melting resistance as loss in weight percent of the initial weight of the ice milk treatments. Results from the same table showed that, the melting resistance of ice milk produced using different levels of substitution of milk fat with RPO was decreased significantly $(p \leq 0.05)$, with the increase of substitution level as compared to control. It could be observed that, $100 \%$ RPO showed the fastest melting rate, while the control ice milk treatment was the lowest. The melting percentage after $10 \mathrm{~min}$. at $25{ }^{\circ} \mathrm{C} \pm 2$ being 10, 11, 13, 16 and $18 \%$ for C, 25, 50,75 and $100 \%$ treatments respectively. In addition, both $75 \%$ and $100 \%$ ice milk treatments were full melted after $50 \mathrm{~min}$, while, other treatments showed more resistance, actually 88, 90, and $100 \%$ for control, 25 and $50 \%$ treatments respectively. These results are nearly in agreement with those reported by Nazaruddin et al., (2008) and Guven et al., (2018). This increase in melting rate were related to the increase of substitution of milk fat with RPO, which may be attributed to the lower melting point of the RPO. These results are nearly in agreement with those reported by Liew et al., (2001) and Rosnani et al., (2007).

\section{Impact of red palm oil incorporation into ice milk formula on fatty acids profiles:}

Fatty acids composition of prepared ice milk as affected by replacing milk fat with different levels $(25,50,75$ and $100 \%)$ of RPO, were determined by gas chromatography and the obtained data are recorded in Table (7). The main fatty acids in the tested ice milk control were myristic, palmitic, stearic and oleic acids which represented $10.62 \%, 34.96 \%, 11.54 \%$ and $25.91 \%$ respectively. Due to blending of RPO at different levels into ice milk, the major changes were noted in the contents of most fatty acids of the resulted ice milk treatments. Blending of RPO with ice milk leading to observably remarkable decrease in most fatty acids content except for palmitic, oleic, linoleic and arachidic acid were a considerable increased.

The fatty acids of ice milk are generally composed of both saturated and unsaturated forms. Table (7) showed that saturated fatty acids contents were 67.10, 61.63, 56.06, 50, 41 and $44.83 \%$ for control, 25, 50, 75 and $100 \%$ treatments respectively.

The total saturated fatty acids of ice milk mixes decreased with the increasing of replacement rate with $\mathrm{RPO}$. This may be attributed to increase in unsaturated fatty acids compared to saturated fatty acids in 100\%RPO, in addition, $25 \%$ and $50 \%$ treatments contained partial whipping cream consists of high palmitic, stearic and oleic acids composition as the milk fat component, so it could affect the fatty acids composition in final ice milk treatments. These results are in close approximately agreement with those reported by Corradini et al., (2014).

The present results in Table (7) showed that ice milk treatments content from unsaturated fatty acids ranged from 29.09 to $43.27 \%$ of total 
fatty acids for control to $100 \%$ red palm oil treatments respectively.

Incorporation RPO into ice milk mixes during formulation exerted marked increase in the oleic acid ( $\omega 9)$ content from 25.91 to $42.62 \%$ of total fatty acids for control ice milk to $100 \%$ RPO treatments respectively. Moreover, the Linoleic acid $(\omega 6)$ content in ice milk treatments increased from 2.95 to $11.53 \%$ of total fatty acids, while the Palmitoleic acid content was decreased with the increase of incorporation of RPO into ice milk treatments, it ranged from 3.18 to $0.65 \%$ of total fatty acids for control, to $100 \%$ red palm oil treatments respectively. This may be due to the decrease in whipping cream quantity. Since the whipping cream was not a good source of linoleic and linoleinic acid, the incorporation of red palm oil in ice milk had boosted up the quantity of both fatty acids. These results are in close approximately agreement with those reported by Rosnani et al., (2007) and Corradini et al., (2014).

The importance of incorporation of red palm oil into ice milk, not only for its high content from unsaturated fatty acids, but also for improving various characteristics such as providing a good balance for omega6/omega 3 ratio. Increasing the carotenoid and omega- 6 intake is essential to improve health, prevention and management of chronic disease by reducing the risk of cardiovascular disease (CVD), obesity, diabetes, inflammation, and several neurological diseases. Furthermore, the balance of omega- 6 and omega- 3 fatty acids is very important for homeostasis and normal development (Watson and Preedy 2012 and Mafra et al., 2014).

\section{Color values of different ice milk treatments:}

The data from Table (8) showed that the results of color for ice milk produced by using $100 \%$ fresh cream as a control sample and ice milk samples which substituted with 25, 50, 75 and $100 \%$ red palm oil immediately after processing. From statistical analysis of these results, it could be observed that, there were significant differences $(p \leq 0.05)$ in the color between all ice milk treatments and the control sample.

The color analysis showed that the Lightness (L*) exhibited decreasing trend, with the increasing of the percentage of red palm oil replacement in ice milk. It was noticed that the replacement of $100 \%$ red palm oil in ice milk showed the least Lightness value (94.27) respectively compared the control sample (99.36). On the other hand, the redness ( $\left.\mathbf{a}^{*}\right)$ and the yellowness $\left(b^{*}\right)$ values of ice milk treatments were increased from (6.82 and 18.55 to 8.38 and 41.12 respectively) with increasing the percentage of RPO replacement compared to the control sample $(2.54$ and 2.06 respectively).

As regards the chroma color and total intensity values were significant differences $(p \leq 0.05)$ between all ice milk treatments and the control sample ice milk. The ice milk samples containing 25\%,50,75 and 100\% RPO for Chroma were (39.06),(54.73),(93.24) and (176.10) respectively compared the control sample (10.70) and total intensity between all ice milk treatments and the control sample, the ice milk samples containing $25 \%, 50,75$ and $100 \%$ RPO for total intensity were (48.12),(47.28),(46.55) and (45.16) respectively compared the control sample (49.41). However the blending of RPO with ice milk leaded to a considerable improvement in the color values of ice milk, this is could be attributed mainly to high levels beta carotenes of fresh RPO.These results are nearly in agreement with those obtained by Nazaruddin et al., (2008) and Kavak and karabiyik (2019).

\section{Effect of preparation the ice milk and their different treatments on carotenoid and vitamin $\mathrm{E}$ contents:}

The present data in Table (9) shown that carotenoid and vitamin E contents of the control sample ice milk and their different treatments containing $(25,50,75$ and $100 \%$ RPO were determined in ice milk mix during preparation of the mixture and after the processing of the final product ice milk to evaluate the loss and their changes during product.

As illustrated in the obtained results Table (9), there were significant $(p \leq 0.05)$ in the carotenoid and vitamin $\mathrm{E}$ contents of various ice milk treatments and ice milk control sample affected by preparation methods (heat, pasteurization at $85^{\circ} \mathrm{C}$ for 15 second).Initial carotenoids contents were (ppm): 170.37 for ice milk mix with $100 \mathrm{RPO}$ compared 25.11 for control sample before production. Carotenoid contents for this sample might be duo to the carotenoid in raw materials 260 (ppm) mango pulp, 0.63 (ppm) milk and red palm oil contain the highest amount of carotenoids among the ingredients 630.33ppm (Underwood, 2000 and Ribeiro et al., 2007).

After product a reduction in carotenoids (2.74\% to $8.36 \%$ ) occurred during product Table (9).Mean value in ice milk mix during processing of the mixture before production (25.11ppm) was significantly reduced (23.01 ppm) after the processing of the final product 
ice milk with the mean loss of $8.36 \%$ for the control sample. The percentage of red palm oil at $25,50,75$ and $100 \%$ reduced the percentage loss in carotenoids $4.21,3.98,2.90$ and $2.74 \%$ respectively. The gradual decrease of carotenoids was observed in all treatments. This result was nearly agreement with Nazaruddin et al., (2008) and Brito and Pinho (2016).

The lowest of reduction in carotenoid and vitamin $\mathrm{E}$ content of ice milk treatments containing $(25,50,75$ and $100 \%)$ compared to ice milk control may be due to the highest amount of carotenoid and vitamin $E$ for fresh RPO, also the RPO is thoroughly blended with other ingredients like, sugar and milk, thereby avoiding direct exposure to heat, probably the retention is higher. The present results are conformity with data obtained by Manorama and Rukomini (1991) and Debier et al., (1999).

The same trend was observed with vitamin E contents the content of vitamin E were decreased from 2.16 to 2.13 ppm for ice milk mix with $100 \%$ RPO while decreased from 0.40 to $0.38 \mathrm{ppm}$ for control sample ice milk before and after production respectively. After product a reduction in vitamin $\mathrm{E}(0.93 \%$ to $2.65 \%$ ) occurred during product Table (9).Mean value in ice milk mix during processing of the mixture before production (0.40 ppm) was significantly reduced $(0.38 \mathrm{ppm})$ after the processing of the final product ice milk with the mean loss of $2.65 \%$ for the control sample. The percentage of RPO at 25, 50, 75 and 100\% reduced the percentage loss in carotenoids 2.40 , $2.34,1.74$ and $0.93 \%$ respectively. The gradual decrease of vitamin $\mathrm{E}$ was observed in all treatments this trend results was observed by Debier et al., (1999).

\section{Sensory evaluation of ice milk affected by different levels of substitution of milk fat with red palm oil:}

Organoleptic properties of food products are important monitoring method which indicate the food acceptability to consumers, sensory evaluation was carried out to evaluate flavor, body and texture, melting quality, appearance and overall acceptability of the resultant products, which achieved by twenty experienced panelists; members of Dairy and Food science Departments, faculty of Agric., AlAzhar Univ., Cairo, Egypt.

Data presented in Table (10), declared that incorporation of red palm oil affect the flavor of the resultant ice milk significantly. The changing in flavor (from 30 point) was ranged from 28.22 to 26.62 points, for control ice milk to $100 \%$ red palm oil treatment. These low scores for both mouth feel and flavor for ice milk with red palm oil at different levels could attribute to the slight flavor of red palm oil, which found not commonly accepted by some panelists.

The obtained results revealed that sweetness for ice milk slightly decreased from control to $100 \%$ red palm oil treatments. This may be due to the presence of whipping cream, which contributes to some sweet sensation. Thus, it can be concluded that, increasing red palm oil substitution levels caused the decrease in sweetness levels substantially. This result is a proximately in agreement with those reported by Dian et al., (2017) they reported that, mild increase in perceived sweetness was found with higher dairy fat content in ice cream.

Aroma acceptability showed a lower score for ice milk treatments with high red palm oil content as compared to control ice milk; this might probably due to lower content of whipping cream which responsible for release of volatile aromatic compound as compared to control sample. The degrees of flavor preference decreased as the concentration of dairy fat used decreased. These findings are in agreement with Corradini et al., (2014), who reported that a decrease in fat content resulted in a lower flavor release in ice milk.

The obtained results from the same Table (10), revealed that creaminess attributes was in decreasing trend when RPO levels increased into ice milk. Therefore, as the dairy fat content decreased, smoothness of the ice milk decreased. These obtained results are in agreement with the findings of Frost and Janhoj (2007) and Corradini et al., (2014), they reported that ice milk creaminess attribute was associated with milk fat globules in dairy products. Thus, reduction of the whipping cream from control to $100 \%$ red palm oil treatments caused the decrease of creaminess.

The melting resistances for ice milk treatments ranged from 18.09 to 17.05 for control to $100 \%$ respectively. Ice milk $25 \%$ RPO treatment firmness was not affected by incorporation of red palm oil into ice milk as compared to control, whereas, there were no significantly decreased for $50 \%, 75 \%$ and $100 \%$ red palm oil treatments as compared to control, this may be due to the melting point of the RPO $\left(38^{\circ} \mathrm{C}\right)$. So, by reducing the amount of dairy fat, the firmness of resultant ice creams containing red palm oil not affected. These findings in agreement with Liew et al., (2001) and Rosnani et al., (2007), they found that the higher 
proportion of palm oil used to replace dairy fat, the lower the firmness of ice milk.

Concerning appearance, it could be noticed from the data obtained that a was positively correlated to yellowness intensity, when the ratio of RPO to whipping cream increased from $25 \%$ to $100 \%$ red palm oil treatments. These results may be attributed to contain red palm oil on large amounts of carotene strong yellow color in nature form had apparently contributed to the yellowness color of finished ice milk. This results in agreement with Wan et al., (2009) who suggested that the amount of red palm oil substitution was positively correlated to yellowness intensity.

\section{CONCLUSIONS}

In conclusion, the present study has shown that mixture of formulation with red palm oil as a fat replacer gave suitable characteristics for ice milk production. This can contribute to soft and smooth in ice milk texture. Red palm oil also influences the melting resistance, which gave lower melting resistance than other formulations. The combination of red palm oil contributes to more intensity in yellowness as beta carotene, vitamin E, viscosity and percentage of overrun of formulation.

\section{REFERENCES}

Lebesi, D.M., Tzia, C., 2011. Effect of the addition of different dietary fiber and edible cereal bran sources on the baking and sensory characteristics of cupcakes. Food Bioprocess Tech., 4 (5), 710-722.

A.O.A.C, 2016. Association of Official Analytical Chemist. Official Methods of Analysis. 19th edition, Washington D.C., USA.

Alina, A.R., Mashitoh, A.S., Babji, A.S., Maznah, I., Syamsul, K.M.W., Muhyiddin, Y. 2012. Oxidative stability of smoked chicken sausage substituted with red palm mid fraction during chilled storage. World Appl. Sci. J., 17 (Sup 1), 62-66.

Bajwa, U.A., Huma, N.U.Z.H.A.T., Ehsan, B.A.B.A.R., Jabbar, K.A.S.H.I.F. Khurrama, A., 2003. Effect of different concentrations of strawberry pulp on the properties of ice cream. Int. J. Agric. Biol., 5 (4), 635-637.

Balthazar, C.F., Gaze, L.V., Azevedo da Silva, H.L., Pereira, C.S., Franco, R.M., ConteJúnior, C.A., de Oliveira Silva, A.C., 2015. Sensory evaluation of ovine milk yoghurt with inulin addition. Int. J. Dairy Tech., 68 (2), 281-290.

Beku, S.P., 2015. Vitamin E contents and oxidative stability of red palm oils blended chicken nuggets during frozen storage. Malays. J. Anal. Sci., 19 (1), 202-212.

Berger, K.G. 2007. Trans-free fats with the products of the oil palm -A selective review. Czech J. Food Sci., 25 (4), 174-181.

Brito, T.C., Pinho, S.C.D., 2016. Characterization and evaluation of sensory acceptability of ice creams incorporated with beta-carotene encapsulated in solid lipid microparticles. Food Sci. Technol., 36 (4), 664-671.

Butt, M.S., Rasool, J., Sharif, K., 2006. Note. Preparation and characterisation of cake rusks by using red palm oil fortified shortening. Food Sci. Technol. Int., 12 (1), 85-90.

Cassiday, L., 2017. Red palm oil. J. Am. Oil Chem. Soc., 28 (2), 1-9.

Corradini, S.A.S., Madrona, G.S., Visentainer, J.V., Bonafe, E.G., Carvalho, C.B., Roche, P.M., Prado, I.N., 2014. Sensorial and fatty acid profile of ice cream manufactured with milk of crossbred cows fed palm oil and coconut fat. J. Dairy Sci., 97 (11), 6745-6753.

Coultate, T.P., 2009. Food: the chemistry of its components. Royal Society of Chemistry. Cambridge, UK.

Cruz, A.G., Antunes, A.E., Sousa, A.L.O., Faria, J.A., Saad, S.M., 2009. Ice-cream as a probiotic food carrier. Food Res. Int., 42 (9), 1233-1239.

Dauqan, E., Sani, H.A., Abdullah, A., Kasim, Z.M., 2011. Effect of different vegetable oils (red palm olein, palm olein, corn oil and coconut oil) on lipid profile in rat. Food Nutr. Sci., 2 (4), 253-258.

Debier, C., Kovacs, K.M., Lydersen, C., Mignolet, E., Larondelle, Y., 1999. Vitamin E and vitamin A contents, fatty acid profiles, and gross composition of harp and hooded seal milk through lactation. Can. J. Zool., 77 (6), 952-958.

Dian, N.L.H.M., Hamid, R.A., Kanagaratnam, S., Isa, W.R.A., Hassim, N.A.M., Ismail, N.H., Sahri, M.M., 2017. Palm oil and palm kernel oil: Versatile ingredients for food applications. J. Oil Palm Res., 29 (4), 487-511.

Ebong, P.E., Owu, D.U., Isong, E.U., 1999. Influence of palm oil (Elaesis guineensis) on health. Plant Foods Human Nutr., 53 (3), 209-222.

Edem, D.O., 2002. Palm oil: biochemical, physiological, nutritional, hematological, and toxicological aspects: a review. Plant Foods Human Nutr., 57 (3-4), 319-341.

Egyptian Standard Specifications. 2005. Ice milk and ices (ice cream), Egyptian Organization for Standardization and Quality Control. No. 3-1185, Cairo, Egypt. 
El-Hadad, N., Abou-Gharbia, H.A., El-Aal, M.H.A., Youssef, M.M., 2010. Red palm olein: Characterization and utilization in formulating novel functional biscuits. J. Am. Oil Chem. Soc., 87 (3), 295-304.

El-Sheshetawy, H.E., Mossad, A., El-helew, W.K., Farina, V., 2016. Comparative study on the quality characteristics of some Egyptian mango cultivars used for food processing. Ann. Agric. Sci., 61 (1), 49-56.

Farhoosh, R., Moosavi, S.M.R., 2007. Rancimat test for the assessment of used frying oils quality. J. Food lipids, 14 (3), 263-271.

Fox, P.F., 2013. Advanced Dairy Chemistry Volume 3: Lactose, Water, Salts and Vitamins. London, Chapman and Hall. pp77-126.

Frost, M.B., Janhoj, T. 2007. Understanding creaminess. Int. Dairy J., 17 (11), 1298-1311.

Galoburda, R., Boca, S., Skrupskis, I., Seglina, D., 2014. Physical and chemical parameters of strawberry puree. In $9^{\text {th }}$ Baltic Conference on Food Science and Technology "Food for Consumer Well-Being", p. 172.

Gee, P.T., 2007. Analytical characteristics of crude and refined palm oil and fractions. Eur. J. Lipid Sci. Technol., 109 (4), 373-379.

Gibon, V., De Greyt, W., Kellens, M., 2007. Palm oil refining. Eur. J. Lipid Sci. Technol., 109 (4), 315-335.

Goff, H.D., Hartel, R.W., 2013. Mix processing and properties. In Ice cream. Springer, Boston, MA. pp. 121-154.

Gupta, M., 2017. Practical Guide to Vegetable Oil Processing. Elsevier, Netherland.

Guven, M., Kalender, M., Taşpinar, T., 2018. Effect of using different kinds and ratios of vegetable oils on ice cream quality characteristics. Foods, 7 (7), 104-125.

Hoyland, D.V., Taylor, A.J., 1991. A review of the methodology of the 2-thiobarbituric acid test. Food Chem., 40 (3), 271-291.

Kavak, D.D., karabiyik, H., 2019. Quality evaluation of kashar cheese: influence of palm oil and ripening period. Food Sci. Technol., 40 (2), 354-360.

Kirk, R.S., Sawyer, R., 1991. Pearson's Composition and Analysis of Foods. 9th edn. Harlow: AWL.

Kumar, M., 2013. Development of Fibre Fortified Low Fat Cranberry Ice Cream. PhD Thesis. National Dairy Research Institute. Deemed University, Karnal, India.

Kumar, P.P., Krishna, A.G. 2014. Physicochemical characteristics and nutraceutical distribution of crude palm oil and its fractions. Grasas Aceites, 65 (2), e018.
Kumar, P.P., Jeyarani, T., Krishna, A.G., 2016. Physicochemical characteristics of phytonutrient retained red palm olein and butter-fat blends and its utilization for formulating chocolate spread. J. Food Sci. Technol., 53 (7), 3060-3072.

Kumar, P., Mishra, H.N., 2003. Effect of mango pulp and soymilk fortification on the texture profile of set yoghurt made from buffalo milk. J. Texture Studies, 34 (3), 249-269.

Leonardis, A., Cuomo, F., Macciola, V., Lopez, F., 2016. Influence of free fatty acid content on the oxidative stability of red palm oil. RSC Advances, 6 (103), 101098-101104.

Li, S., Li, L., Zeng, Q., Liu, J., Ren, D., 2016. Separation and quantification of milk casein from different buffalo breeds. J. Dairy Res., 83 (3), 317-325.

Liew, M.Y.B., Ghazali, H.M., Yazid, A.M., Lai, O.M., Chow, M.C., Yusoff, M.S.A., Long, K., 2001. Rheological properties of ice cream emulsion prepared from lipase-catalyzed transesterified palm kernel olein: anhydrous milk fat mixture. J. Food Lipids, 8(2), 131146.

Lim, C.W., Norziah, M.H., Lu, H.F.S. 2010. Effect of flaxseed oil towards physicochemical and sensory characteristic of reduced fat ice creams and its stability in ice creams upon storage. Int. Food Res. J., (17), 393-403.

Mafra, D., Lobo, J.C., Barros, A.F., Koppe, L., Vaziri, N.D., Fouque, D., 2014. Role of altered intestinal microbiota in systemic inflammation and cardiovascular disease in chronic kidney disease. Future Microbiol., 9 (3), 399-410.

Mamat, H., Aini, I.N., Said, M., Jamaludin, R., 2005. Physicochemical characteristics of palm oil and sunflower oil blends fractionated at different temperatures. Food Chem., 91(4), 731-736.

Manorama, R., Rukmini, C., 1991. Effect of processing on $\beta$-carotene retention in crude palm oil and its products. Food Chem., 42 (3), 253-264.

Mariod, A., Ismail, M., Rahman, N.A., Matthaus, B., 2014. Stability of rice bran oil extracted by SFE and Soxhlet methods during accelerated shelf-life storage. Grasas Aceites, 65 (1), 1-11.

Marshall, R.T., Goff, D., 2003. Formulating and manufacturing ice cream and other frozen desserts: Frozen desserts: formulating, manufacturing, and marketing. Food Technol., 57 (5), 32-45.

Mba, O.I., Dumont, M.J., Ngadi, M., 2015. Palm oil: Processing, characterization and 
utilization in the food industry-A review. Food Biosci, 10 (1), 26-41.

Naghshineh, M., Ariffin, A.A., Ghazali, H.M., Mirhosseini, H., Mohammad, A.S., 2010. Effect of saturated/unsaturated fatty acid ratio on physicochemical properties of palm olein-olive oil blend. J. Am. Oil Chem. Soc., 87 (3), 255-262.

Nazaruddin, R., Syaliza, A.S., Wan Rosnani, A.I., 2008. The effect of vegetable fat on the physicochemical characteristics of dates ice cream. Int. J. Dairy Technol., 61 (3), 265-269.

Neo, Y.P., Ariffin, A., Tan, C.P., Tan, Y.A., 2008. Determination of oil palm fruit phenolic compounds and their antioxidant activities using spectrophotometric methods. Int. J. Food Sci. Technol., 43(10), 1832-1837.

Nor Aini, I., Miskandar, M.S. 2007., Utilization of palm oil and palm products in shortenings and margarines. Eur. J. Lipid Sci. Technol., 109 (4), 422-432.

Ong, A.S.H., Goh, S.H., 2002. Palm oil: a healthful and cost-effective dietary component. Food Nutr. Bull., 23(1), 11-22.

Ribeiro, S.M.R., Queiroz, J.H., de Queiroz, M.E.L.R., Campos, F.M., Sant'Ana, H.M.P., 2007. Antioxidant in mango (Mangifera indica L.) pulp. Plant Foods Human Nutr., 62 (1), 13-17.

Riuz, A., Ayora-Canada, M.J. Lendl, B., 2001. A rapid method for peroxide value determination in edible oils based on flow analysis with Fourier transform infrared spectroscopic detection. Analyst, 126 (2), 242-246.

Rooyen, J., van Esterhuyse, A.J., Engelbrecht, A.M., Toit, E.F., 2008. Health benefits of a natural carotenoid rich oil: a proposed mechanism of protection against ischaemia/reperfusion injury. Asia Pacific J. Clin. Nutr., 17, (1), 316-319.

Rosnani, A.I., Aini, I.N., Yazid, A.M.M., Dzulkifly, M.H., 2007. Flow properties of ice cream mix prepared from palm oil: anhydrous milk fat blends. Pak. J. Biol. Sci., 10 (10), 1691-1696.

Rossi, M., Alamprese, C., Ratti, S., 2007. Tocopherols and tocotrienols as free radical- scavengers in refined vegetable oils and their stability during deep-fat frying. Food Chem., 102(3):812-817.

Santillan-Urquiza, E., Ruiz-Espinosa, H., Angulo-Molina, A., Ruiz, J.F.V., MendezRojas, M.A., 2017. Applications of nanomaterials in functional fortified dairy products: benefits and implications for human health. In Grumezescu, A. M. (Ed.), Nanotechnology in the agri-food industry, Nutrient Delivery. Elsevier Inc. Netherlands, pp- 293-328.

Sellami, M., Ghamgui, H., Frikha, F., Gargouri, Y. Miled, N., 2012. Enzymatic transesterification of palm stearin and olein blends to produce zero-trans margarine fat. BMC Biotechnol. 48 (12), 2-8.

Siew, W.L., 2005. Chemical and physical characteristics of palm and palm kernel oils and their crystallization behaviour. 25th Palm Oil Familiarization Programme, Kuala Lumpur, Malaysia. pp.294-311.

Szucs, G., Bester, D.J., Kupai, K., Csont, T., Csonka, C., Esterhuyse, A.J., Ferdinandy, P., Van Rooyen, J., 2011. Dietary red palm oil supplementation decreases infarct size in cholesterol fed rats. Lipids Health Dis., (10), 103-107.

Underwood, B.A., 2000. Dietary approaches to the control of vitamin A deficiency: an introduction and overview. Food Nutr. Bull., 21 (2), 117-123.

Van Jaarsveld, P.J., Marais, D.W., Harmse, E., Nestel, P., Rodriguez-Amaya, D.B., 2006. Retention of $\beta$-carotene in boiled, mashed orange-fleshed sweet potato. J. Food Compos. Anal., 19 (4), 321-329.

Wan, R.A.I., Nor Aini, I., Abdul Rahman, I., 2009. Physical properties of red palm-based ice cream. Oil Palm Bull., 59 (11), 18-24.

Watson, R.R., Preedy, V.R., 2012. Bioactive Food as Dietary Interventions for Cardiovascular Disease: Bioactive Foods in Chronic Disease States. Elsevier. Boston, MA. 
Table 1. formulation of control ice milk and with different levels (25, 50, 75 and $100 \%)$ red palm oil as fat milk replacer.

\begin{tabular}{cccccc}
\hline Ingredients (g or ml) & Control & $\mathbf{2 5 \%}$ & $\mathbf{5 0 \%}$ & $\mathbf{7 5 \%}$ & $\mathbf{1 0 0 \%}$ \\
\hline Fresh skim milk & 49.86 & 51.11 & 52.37 & 53.61 & 54.86 \\
Fresh cream (50\%) & 10 & 7.5 & 5 & 2.5 & - \\
Skim milk powder & 9.44 & 9.44 & 9.43 & 9.44 & 9.44 \\
Sucrose & 15 & 15 & 15 & 15 & 15 \\
Mango pulp & 15 & 15 & 15 & 15 & 15 \\
Cremodan Se 734 Veg & 0.7 & 0.7 & 0.7 & 0.7 & 0.7 \\
Red palm oil & - & 1.25 & 2.5 & 3.75 & 5 \\
Total & $100 \mathrm{~g}$ & $100 \mathrm{~g}$ & $100 \mathrm{~g}$ & $100 \mathrm{~g}$ & $100 \mathrm{~g}$ \\
\hline
\end{tabular}

Table 2. Physico-chemical properties of red palm oil.

\section{Physico-chemical properties}

\begin{tabular}{llll}
\hline & $\mathrm{L}^{*}: \quad 44.34$ & & \\
Color & $\mathrm{a}^{*}: \quad 57.12$ & Acidity \% (as palmitic acid) & 0.192 \\
& $\mathrm{~b}^{*}: \quad 63.26$ & & \\
\hline Density & 0.9063 & peroxide value (meq.O $/ \mathrm{kg}$ oil) & 0.823 \\
\hline Rafractive index at $25^{\circ} \mathrm{C}$ & 1.4552 & Iodine value (Hanus) & 53.10 \\
\hline Melting point $\left({ }^{\circ} \mathrm{C}\right)$ & 38.00 & T.B.A(mg malonaldehyde $/ \mathrm{kg}$ oil $)$ & 0.08 \\
\hline Smoking point $\left({ }^{\circ} \mathrm{C}\right)$ & 235 & Saponification value (mg KOH/g oil) & 193.42 \\
\hline Slip Melting Point $\left({ }^{\circ} \mathrm{C}\right)$ & 37.00 & Unsaponification mater \% & 1.33 \\
\hline Viscosity at $25^{\circ} \mathrm{C}$ centipois & 400 & Induction period (h) & 71.00 \\
\hline$L^{*}$ (lightness) $a^{*}$ (redness) & $b^{*}$ (yellowness) & &
\end{tabular}

Table 3. Fatty acid composition of fresh red palm oil.

\begin{tabular}{|c|c|c|}
\hline Fatty acids \% & Common name & Red palm oil \\
\hline (C6:0) & Caproic & 0.00 \\
\hline (C8:0) & Caprylic & 0.04 \\
\hline (C10:0) & Capric & 0.10 \\
\hline (C12:0) & Lauric & 0.22 \\
\hline (C14:0) & Myristic & 1.10 \\
\hline (C16:0) & Palmitic & 37.79 \\
\hline$(\mathrm{C} 16: 1) \omega 7$ & Palmitoleic & 0.56 \\
\hline (C17:0) & Margaric & 0.35 \\
\hline (C18:0) & Stearic & 4.83 \\
\hline$(\mathrm{C} 18: 1) \omega 9$ & Oleic & 42.60 \\
\hline$(\mathrm{C} 18: 2) \omega 6$ & Linoleic & 11.65 \\
\hline
\end{tabular}




\begin{tabular}{|c|c|c|}
\hline Fatty acids $\%$ & Common name & Red palm oil \\
\hline$(\mathrm{C} 18: 3) \omega 3$ & Linolenic & 0.45 \\
\hline (C20:0) & Arachidic & 0.32 \\
\hline \multicolumn{2}{|c|}{ Total SFAs } & 44.75 \\
\hline \multicolumn{2}{|c|}{ Total MUFAs } & 43.16 \\
\hline \multicolumn{2}{|c|}{ Total PUFAs } & 12.10 \\
\hline
\end{tabular}

Table 4. phytonutrients concentration of red palm oil and Recommended Dietary Allowance (RDA. $\mu \mathrm{g} /$ day) and grams daily intake from red palm oil.

\begin{tabular}{cccc} 
Phytonutrients & $\begin{array}{c}\text { Concentration } \\
(\mathbf{p p m})\end{array}$ & $\begin{array}{c}\text { RDA } \\
(\boldsymbol{\mu} \mathrm{g} / \mathrm{day})\end{array}$ & $\begin{array}{c}\text { Amount (g)that } \\
\text { supply the RDA }\end{array}$ \\
\hline B-Carotenes & 650.33 & 2400 & 3.70 \\
Vitamin E & 710 & 10000 & 14.08 \\
Vitamin A & 1.72 & 600 & 348.83 \\
Lycopene & 1.62 & 33.39 & 20.61 \\
Phenolic Compounds & 220.34 & 863 & 3.80 \\
\hline
\end{tabular}

Table 5. Physiochemical properties for ice milk and their different treatments.

$\begin{array}{llll}\text { Item } & \text { Acidity } \% & \mathrm{pH} & \text { Viscosity cPs }\end{array}$

Treatments

$\begin{array}{cccc}\text { Control } & 0.29^{\mathrm{A}} & 6.20^{\mathrm{A}} & 27^{\mathrm{A}} \\ \mathbf{2 5 \%} & 0.29^{\mathrm{A}} & 6.18^{\mathrm{A}} & 26^{\mathrm{B}} \\ \mathbf{5 0} \% & 0.30^{\mathrm{A}} & 6.18^{\mathrm{A}} & 25^{\mathrm{C}} \\ \mathbf{7 5 \%} & 0.31^{\mathrm{A}} & 6.15^{\mathrm{A}} & 23^{\mathrm{D}} \\ \mathbf{1 0 0 \%} & 0.33^{\mathrm{A}} & 6.14^{\mathrm{A}} & 22^{\mathrm{E}}\end{array}$

Means values in the same column showed the same superscript letter is not significantly different $(p \leq 0.05)$.

Table 6. Overrun and melting rate of ice milk and their different treatments.

\begin{tabular}{|c|c|c|c|c|c|c|c|}
\hline \multirow{2}{*}{$\begin{array}{c}\text { Item } \\
\text { Treatments }\end{array}$} & \multirow{2}{*}{ Overrun \% } & \multicolumn{6}{|c|}{ Melting rate $(\mathrm{g} / \mathrm{min})$ at $25^{\circ} \mathrm{C}$. } \\
\hline & & $10 \mathrm{~min}$ & $20 \mathrm{~min}$ & $30 \mathrm{~min}$ & $40 \mathrm{~min}$ & $50 \mathrm{~min}$ & $60 \mathrm{~min}$ \\
\hline Control & $70^{\mathrm{A}}$ & $10^{\mathrm{A}}$ & $23^{\mathrm{A}}$ & $35^{\mathrm{A}}$ & $57 \mathrm{~A}$ & $75^{\mathrm{A}}$ & $88^{\mathrm{A}}$ \\
\hline $25 \%$ & $69^{\mathrm{B}}$ & $11^{\mathrm{B}}$ & $27^{\mathrm{B}}$ & $38^{\mathrm{B}}$ & $60^{\mathrm{B}}$ & $78^{\mathrm{B}}$ & $90^{\mathrm{B}}$ \\
\hline $50 \%$ & $66^{C}$ & $13^{c}$ & $33 \mathrm{C}$ & $44^{C}$ & $72 \mathrm{C}$ & $88^{C}$ & $100^{C}$ \\
\hline $75 \%$ & $64^{\mathrm{D}}$ & $16^{\mathrm{D}}$ & $45^{\mathrm{D}}$ & $60^{\mathrm{D}}$ & $83^{\mathrm{D}}$ & $100^{\mathrm{D}}$ & - \\
\hline $100 \%$ & $62^{\mathrm{E}}$ & $18^{\mathrm{E}}$ & $55^{\mathrm{E}}$ & $72^{\mathrm{E}}$ & $89^{\mathrm{E}}$ & $100^{\mathrm{D}}$ & - \\
\hline
\end{tabular}

Means values in the same column showed the same superscript letter is not significantly different $(\mathrm{p} \leq 0.05)$.

Table 7. Fatty acids profiles of ice milk affected by levels of red palm oil as partial milk fat.

\begin{tabular}{ccccccc}
\hline Fatty acids $\%$ & Common name & Control & $\mathbf{2 5 \%}$ & $\mathbf{5 0 \%}$ & $\mathbf{7 5 \%}$ & $\mathbf{1 0 0} \%$ \\
\hline & & & & & & \\
\hline (C4:0) & Butyric & 1.47 & 1.12 & 0.76 & 0.37 & 0 \\
(C6:0) & Caproic & 1.22 & 0.92 & 0.65 & 0.31 & 0 \\
(C8:0) & Caprylic & 0.69 & 0.53 & 0.37 & 0.2 & 0.04 \\
$(\mathbf{C} 10: 0)$ & Capric & 1.58 & 1.25 & 0.82 & 0.5 & 0.11 \\
$(\mathbf{C} 12: 0)$ & Lauric & 2.02 & 1.57 & 1.12 & 0.67 & 0.22 \\
$(\mathbf{C} 14: 0)$ & Myristic & 10.62 & 8.24 & 5.86 & 3.48 & 1.1 \\
(C16:0) & Palmitic & 34.96 & 35.75 & 36.48 & 37.11 & 37.82 \\
\hline
\end{tabular}




\begin{tabular}{|c|c|c|c|c|c|c|}
\hline Fatty acids \% & Common name & Control & $25 \%$ & $50 \%$ & $75 \%$ & $100 \%$ \\
\hline$(\mathrm{C} 16: 1) \omega 7$ & Palmitoleic & 3.18 & 2.54 & 1.91 & 1.28 & 0.65 \\
\hline (C17:0) & Margaric & 2.65 & 2.09 & 1.52 & 0.95 & 0.37 \\
\hline (C18:0) & Stearic & 11.54 & 9.92 & 8.21 & 6.53 & 4.85 \\
\hline$(\mathrm{C} 18: 1) \omega 9$ & Oleic & 25.91 & 30.1 & 34.29 & 38.49 & 42.62 \\
\hline 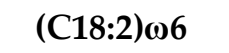 & Linoleic & 2.95 & 4.38 & 6.85 & 9.23 & 11.53 \\
\hline 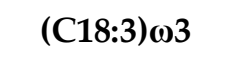 & Linolenic & 0.85 & 0.77 & 0.68 & 0.57 & 0.4 \\
\hline (C20:0) & Arachidic & 0.35 & 0.24 & 0.27 & 0.29 & 0.32 \\
\hline \multicolumn{2}{|c|}{ Total SFAs } & 67.10 & 61.63 & 56.06 & 50.41 & 44.83 \\
\hline \multicolumn{2}{|c|}{ Total MUFAs } & 29.09 & 32.64 & 36.20 & 39.77 & 43.27 \\
\hline \multicolumn{2}{|c|}{ Total PUFAs } & 3.80 & 5.15 & 7.53 & 9.8 & 11.93 \\
\hline
\end{tabular}

Table 8. Color values of ice milk as affected by different levels of red palm oil:

\begin{tabular}{cccccc}
\hline Substitution $\%$ & $\mathbf{L}^{*}$ & $\mathbf{a}^{*}$ & $\mathbf{b}^{*}$ & Chroma & $\begin{array}{c}\text { Total } \\
\text { intensity }\end{array}$ \\
\hline Control & $99.36^{\mathrm{A}}$ & $2.54^{\mathrm{E}}$ & $2.06^{\mathrm{E}}$ & $10.70^{\mathrm{E}}$ & $49.41^{\mathrm{A}}$ \\
$\mathbf{2 5 \%}$ & $96.10^{\mathrm{B}}$ & $6.82^{\mathrm{D}}$ & $18.55^{\mathrm{D}}$ & $39.06^{\mathrm{D}}$ & $48.12^{\mathrm{B}}$ \\
$\mathbf{5 0 \%}$ & $94.39^{\mathrm{C}}$ & $7.26^{\mathrm{C}}$ & $22.24^{\mathrm{C}}$ & $54.73^{\mathrm{C}}$ & $47.28^{\mathrm{C}}$ \\
$\mathbf{7 5 \%}$ & $91.53^{\mathrm{D}}$ & $7.96^{\mathrm{B}}$ & $29.48^{\mathrm{B}}$ & $93.24^{\mathrm{B}}$ & $46.5^{\mathrm{D}}$ \\
$\mathbf{1 0 0} \%$ & $85.27^{\mathrm{E}}$ & $8.38^{\mathrm{A}}$ & $41.12^{\mathrm{A}}$ & $176.10^{\mathrm{A}}$ & $45.16^{\mathrm{E}}$ \\
\hline
\end{tabular}

Means values in the same column showed the same superscript letter is not significantly different ( $\mathrm{p} \leq 0.05)$. $\mathrm{L}^{*}$ (lightness), $\mathrm{a}^{*}$ (redness), $\mathrm{b}^{*}$ (yellowness).

Table 9. Carotenoid and vitamin E contents of ice milk affected by different levels of substitution of milk fat with red palm oil.

\begin{tabular}{clllll}
\hline Parameter (ppm) & Control & $\mathbf{2 5 \%}$ & $\mathbf{5 0 \%}$ & $\mathbf{7 5 \%}$ & $\mathbf{1 0 0 \%}$ \\
\hline Carotene enriched ice milk mix & $25.11^{\mathrm{E}}$ & $41.24^{\mathrm{D}}$ & $71.58^{\mathrm{C}}$ & $134.75^{\mathrm{B}}$ & $170.37^{\mathrm{A}}$ \\
Carotene enriched final ice milk & $23.01^{\mathrm{E}}$ & $39.50^{\mathrm{D}}$ & $68.73^{\mathrm{C}}$ & $130.83^{\mathrm{B}}$ & $165.82^{\mathrm{A}}$ \\
$\begin{array}{c}\text { product } \\
\text { \% Loos }\end{array}$ & 8.36 & 4.21 & 3.98 & 2.90 & 2.74 \\
Vitamin E in ice milk mix & $0.40^{\mathrm{E}}$ & $0.85^{\mathrm{D}}$ & $1.30^{\mathrm{C}}$ & $1.75^{\mathrm{B}}$ & $2.16^{\mathrm{A}}$ \\
Vitamin E in final ice milk product & $0.38^{\mathrm{E}}$ & $0.81^{\mathrm{D}}$ & $1.25^{\mathrm{C}}$ & $1.69^{\mathrm{B}}$ & $2.13^{\mathrm{A}}$ \\
\% Loos & 2.56 & 2.40 & 2.34 & 1.74 & 0.93 \\
\hline
\end{tabular}

Means values in the same row showed the same superscript letter is not significantly different $(\mathrm{p} \leq 0.05)$.

Table 10. Sensory evaluation of ice milk as affected by different levels of red palm oil.

\begin{tabular}{cccccc}
\hline Properties & Control & $\mathbf{2 5 \%}$ & $\mathbf{5 0 \%}$ & $\mathbf{7 5 \%}$ & $\mathbf{1 0 0 \%}$ \\
\hline Flavor (30) & $28.22^{\mathrm{A}}$ & $28.30^{\mathrm{A}}$ & $28.09^{\mathrm{A}}$ & $27.89^{\mathrm{B}}$ & $26.62^{\mathrm{C}}$ \\
Body and Texture (30) & $29.11^{\mathrm{A}}$ & $28.33^{\mathrm{B}}$ & $28.25^{\mathrm{B}}$ & $27.46^{\mathrm{C}}$ & $26.9^{\mathrm{D}}$ \\
Melting quality (20) & $18.21^{\mathrm{A}}$ & $18.09^{\mathrm{A}}$ & $17.66^{\mathrm{A}}$ & $17.27^{\mathrm{A}}$ & $17.05^{\mathrm{A}}$ \\
Appearance (20) & $17.66^{\mathrm{B}}$ & $18.55^{\mathrm{A}}$ & $18.45^{\mathrm{A}}$ & $17.33^{\mathrm{B}}$ & $15.45^{\mathrm{C}}$ \\
Overall acceptability (100) & $91.33^{\mathrm{B}}$ & $93.21^{\mathrm{A}}$ & $91.20^{\mathrm{B}}$ & $87.66^{\mathrm{C}}$ & $82.6^{\mathrm{D}}$ \\
\hline
\end{tabular}

Means values in the same row showed the same superscript letter is not significantly different $(\mathrm{p} \leq 0.05)$. 


\section{استخدام زيت النخيل الأمر كبديل صحي لدهن اللبن في المثلوجات اللبنية}

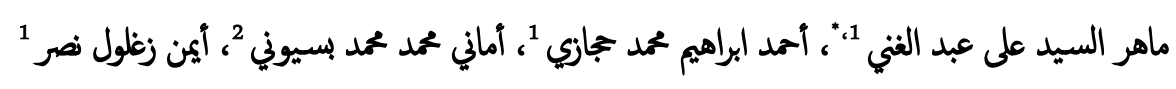

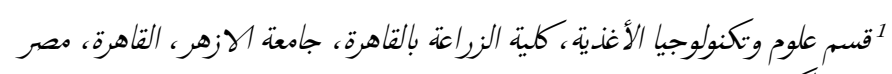

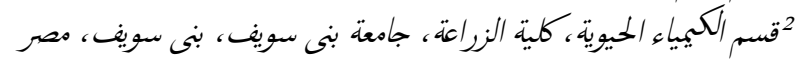

البريد الإليكتروني للباحث الرئيس: MaherAbdelghany2465.el@azhar.edu.eg

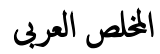

هذا البحث يلقى الضوء على استخدام زيت النخيل الأمر كبديل لدهن اللبن في مكونات المثلوجات اللبنية، كما يوضح تأثير نسب الإستبدال الخخلفة على دلائل

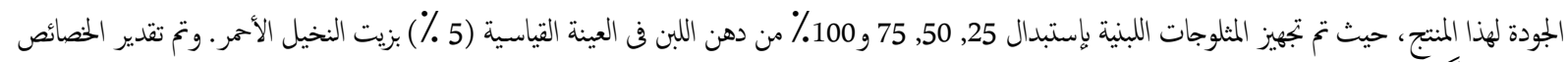

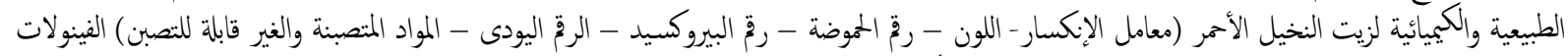

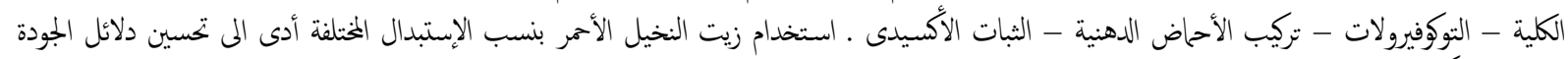

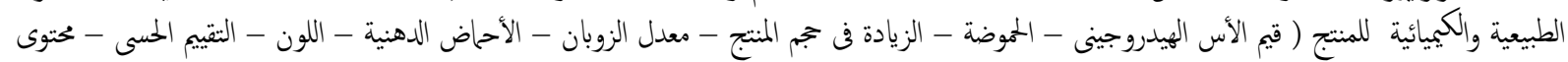

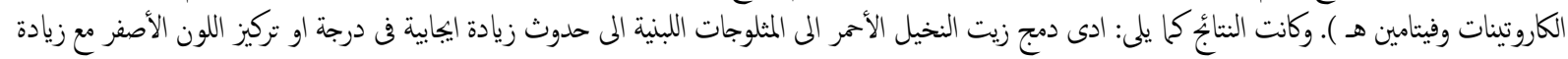

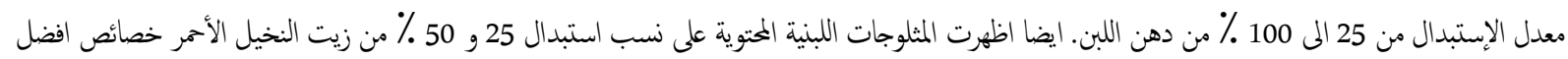

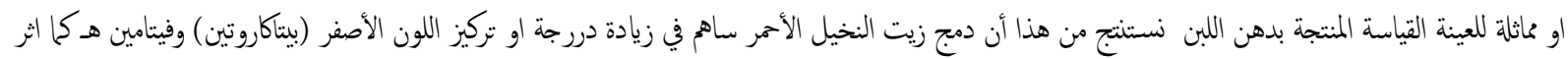
على اللزوجة ونسبة الزيادة في حجم المنتج النهائي. الكلمات المفتاحية: زيت النخيل الاحمر، الايس كزيم، الخواص الطبيعية والكيميائية، الاححاض الدهنية. 